\title{
CURRENT TRENDS AND TASKS OF TRAINING OF LAND MANAGEMENT SPECIALISTS
}

\author{
Vladimir Kosinsky, Mikhail Burov \\ State University of Land Use Planning, Russia
}

\begin{abstract}
In 2015-2016 the State University of Land Use Planning and land management faculties of higher educational institutions released the final mass enrollment of graduates who studied "engineer" qualification for five years. Starting from 2016-2017, bachelors and masters of land management began to leave the walls of the State University of Land Use Planning and land management departments of universities. Has the division into two parts - bachelor's and master's been justified? Basically, we can say that this is an international practice and we would not want to live separately from the international community, since we study foreigners from many countries of the world who want to receive education in a Western way; in addition, our students also study abroad.

But, unlike the Western baccalaureate, we remain specializations. There are profiles in the undergraduate program: land administration, land management, real estate cadastre, urban cadastre, land valuation, real estate valuation, and so on, that is students receive professional knowledge.

Mastership is designed to deepen them. But it is absolutely not necessary to choose undergraduate and graduate programs in the same direction, it can be changed. If a student is not satisfied with the direction or specialization chosen before, he can correct it by studying another mastership program.

One undoubted positive consequence of Russia's accession to the Bologna process is the simultaneous assumption of international obligations to maintain the wide accessibility of higher education regardless of financial situation of young people. Europe seeks to provide broad social protection in this area, where Russia has been catastrophically losing ground in recent years. The United States, with all its wealth, has never tried to positively solve this problem and is not going to accept the Bologna rules, and they have enough compelling arguments for this.

First of all, do we need a bachelor degree? How will a master match with a candidate of science? Today, the heads of land surveying firms and companies, sociologists, professors of universities as well as educational and scientific institutions are discussing this problem.

Keywords: education, digital economy, land use, land management, scientific and technological development.
\end{abstract}

\section{Introduction}

The main theme of the economic development of the Russian Federation in recent years has been the implementation of the national program "Digital Economy of the Russian Federation". Using digital information and communication technologies, the currently established economic, social, and cultural relations between economic entities and consumers of products manufactured by the country's economy, citizens and structures of various forms of ownership providing various services are changing. In our opinion, digitalization contributes to the effective development of individual enterprises, as well as entire industries, and, as a result, to the economy as a whole (Волков и др., 2019).

The president of the Russian Federation V.V. Putin at the meeting of the Council for Strategic Development and Priority Projects on July 5, 2017, dedicated to the digital economy of the Russian Federation, noted that "The digital economy is not a separate industry - in fact, it is a way of life, a new basis for the development of public administration, economy, business, social sphere and the whole society. The formation of digital economy is a matter of national security and independence of Russia; it touches on competition of domestic companies, the country's position on the world stage for the long term, in fact, for decades!" (Путин, 2017) Everywhere in the world, the use of digital technologies is reflected in the development of all sectors of the economy, including agriculture.

So, the digital transformation of the agricultural sector is inevitable. For the optimisation of the country's economy, the most important area of activity of the agro-industrial complex of Russia is the training and retraining of personnel to demanded digital competencies (Стенограмма заседания Совета..., 2016, Стенограмма заседания Совета..., 2016).

Higher land use planning education in Russia is over 180 years. At the beginning of the 20th century, the term "land use planning" began to be used in many spheres of public life and, first of all, in economics, politics, education and science. The words "surveyor", "surveying engineer" began to be replaced by the words "land engineer", and a little later - "land use planning engineer", because these 
experts knew not only the technical and legal, but also the economic, organizational, economic and environmental aspects of land management.

The simplest task in the preparation of engineering and land management personnel was to develop four features in a student: actual knowledge; the mastery; his own point of view and a constant desire for continuing education. If a student understood that he needed these features as a future land use planning engineer, then the effectiveness of training increased significantly.

The future land use planning engineer of those days was studied a wide range of the fundamental sciences, engineering and geodetic technologies. He also studied the basics of agricultural and land policy; organization and production management; jurisprudence; drawing up and signing maps and plans; calligraphy; architecture; geography; statistics; building art; agricultural and forest taxation; soil science; agriculture; understood organization of roads and hydraulic structures, labor relations; psychology and sociology. In addition, He knew the economy well in order to understand the issues of rationing, planning, cost, pricing, working capital, depreciation and other economic categories (Волков, Косинский, 2018).

Applying the acquired knowledge, the land use planning engineer also used his mathematical abilities, drawing and painting. To find the optimal solution to his task, the land use planning engineer, based on his experience and qualifications, could use modeling and mathematical analysis. During experimental work, an engineer, as a rule, set the task in such a way as to obtain the maximum of reliable information with a minimum of time and cost. The accuracy and value of his conclusions based on the results of observations depended on the skill of the engineer in experimenting and conducting measurements.

An engineering point of view is a property that cannot be attributed to either knowledge or experience. The constant and deep interest in his profession, the desire to find out and clarify all the necessary details is one of the components of the engineering point of view. Also very important aspects of profession are objectivity and professional ethics. Another important feature is the willingness to innovation. In this regard, practicing land use planning specialists - teachers in universities always brought new things to the educational process, including modern tools and the latest technologies.

One of the main tasks of engineering education was the development of logical thinking methods among students, the encouragement of the desire to understand everything, the development of the ability to think clearly, and a critical approach to the existing methods - the characteristic of the inventor. Another skill of an engineer, the importance of which is difficult to exaggerate, is the ability to work with people of various professions in order to ensure maximum efficiency of his work. That's how land use planning engineers successfully trained for many decades in the system of Soviet and Russian education.

The state has to decide what kind of specialists it needs today and how many! And what is the end result that we should focus on?!

\section{Methodology of research and materials}

The aim of the article is to evaluate the main criteria for training of land management specialists in Russia in the new conditions of digital economy. In order to achieve the goal, the significance and necessity of the main aspects of bachelor's and master's study programs nowadays have been assessed.

\section{Discussions and results}

Bachelor degree, in our opinion, should form the basic professional competencies of students and prepare ordinary but skilled employees performing executive functions. Now at least $80 \%$ of bachelor's graduates continue education in magistracy (this is a common practice for those countries that just have switched to the Bologna system). In the future, this share is usually reduced to $20 \%$, and instead of master's programs, various advanced training courses are often used.

Magistracy, in our opinion, should prepare specialists capable of solving the most complex, creative problems not only in practical, but also in analytical and research spheres. The magistracy programs should contribute to the further development and promotion of the employee in in-depth and advanced specialization, or in the scientific or managerial spheres. In fact, master's degree is an analogue of the second higher education, or in some cases - an analogue of graduate school.

Many people express concerns that the bachelor's training program is simplified and such an employee cannot cope with his functions, since he is trained one year less than a classical engineer. But, according to the plan of the Ministry of Education and Science of the Russian Federation, the development of the young generation will be carried out not only and not so much through academic disciplines, but through integration into the scientific, industrial and cultural environment of the university. 
However, difficulties with employment stimulate young people to look for an employer as early as possible, almost from the first year of study at a university. There is no country in the world where it is encouraged. Only our legislation provides that if a student is successfully studying, he can work. Using this, students go to work when they need to study. Part-time work is good on vacation, but not during school hours! Otherwise, the student leaves the university with working experience, but with a low quality of knowledge. A university is not only classroom studies, it is communication, science clubs, conferences, discussions, internships abroad, etc. A very important function of the educational process is the acquisition of friends.

The future work teams, the partners are formed within the walls of the university. And if you spent two or four hours at the lectures and fled to work, much of this was lost. Of course, not only students, but also employers are to blame. They require working experience, forgetting that knowledge, skills, competencies is more important. Experience can be acquired during practice, but knowledge is something more difficult.

In land management, the problem with personnel has been extremely acute for over 25 years. That's because of the numerous transformations (from 1991 to 2016 the country's land management authorities were reformed 15 times!) gradually blurred the land management functions and the functions of qualified land use planning personnel. As a result, the value of professionals having a degree and the level of respect for them have been reduced. Business did not and does not make a request to universities: who they need, when and for what tasks. Due to the ongoing trend, the situation in land management remains difficult. Personnel are being changed by so-called "effective managers" who, without knowledge of professional nuances, the essence, goals, objectives and contents of the land management system, ultimately destroy its main tool and the organization of rational land tenure and land use - land management.

The existing success of world scientific and technological leaders are largely determined by the effective integration of science, education and business, which is an effective tool for improving the quality of education and labor, sustainable development and competitiveness of specialists, enterprises, countries and their regions. National land services operate effectively in Sweden, Norway, Finland, Australia, China, the USA, Germany, the Netherlands and other countries, and land management occupies the most important and worthy place in their institutional infrastructure.

In the national economy of our country, we need an investment model with greater competition, without flaws in the business climate and the "dominance" of power structures (Буров, 2011; Буров, Чистяков, 2016). In the formation of a culture of knowledge-based production, education plays an important role, because in modern high-tech production, the more skilled a worker is, the higher his general culture and the quality of his work. The preparation of high-quality workers is one of the fundamental principles of the life of any country.

It must be admitted that the system of higher and secondary special education, and also the personnel retraining system in land management, which developed under the conditions of directive planning and a high degree of population employment, is still slowly rebuilt for new requirements. Educational institutions respond weakly to bringing the educational structure, volumes, programs, profiles, qualifications of training personnel to the requirements of a market economy. The quality of training for a part of graduates of educational institutions does not meet the modern requirements, since sometimes there is no balance in fundamental knowledge and special disciplines. Our task today is introduction mathematics and information technology into curricula, and provision fundamental knowledge at the intersection of economics and information technology, economics and mathematics.

Special studies conducted in the Lipetsk region showed that the most optimal ratio of students in institutions of higher, secondary and primary vocational education is 100: $120: 200$, that is, for every 100 graduates with higher education, 320 graduates with primary and secondary vocational education should be prepared (Буров, 2011).

In the 60s, American economists justified the concept of "half-life of skills," i.e. the period during which the knowledge of a university graduate becomes obsolete and the employee becomes unsuitable for further work. It has been established that after graduating from a higher or secondary specialized educational institution, a former student annually loses about $20 \%$ of knowledge (Административноуправленческий портал, 2020).

In most developed countries, a network of research and testing centers has been formed for the collective use of scientific and testing equipment of various profiles, expensive facilities and complexes. The Centers for Collective Use of Scientific Equipment (CCU) are created, as a rule, in the form of publicprivate partnership. In Russia, the CCU creation is supported by the Ministry of Education and Science 
of the Russian Federation as a part of the federal state scientific and technical program "Research and Development in Priority Directions for the Development of Science and Technology for Civil Use" (Образование и общество..., 2007; Административно-управленческий портал, 2020). Financing of created CCU can be provided at the expense of the regional budget, funds of the Ministry of Education and Science of the Russian Federation, corresponding ministries and departments of the Russian Federation and extrabudgetary sources (such as manufacturers of equipment, materials, structures, investors, research organizations, self-regulatory organizations, etc.). The role of the teachers and students of universities is invaluable here.

For the economy development it is also necessary to create centers of competence, which should provide intellectual, personnel support for projects related to the formation of new markets and new industries. The activities of such centers should be closely integrated with the education system, the economy, hightech firms and companies.

At present, Russia is in the fifth place in the world in terms of budget financing of the scientific sphere, but the share of extrabudgetary funding remains low (Стенограмма заседания Совета..., 2016).

Unfortunately, participants in the land management business recall the existence of land management science when force majeure circumstances or controversial, unresolved issues arise, or, for examples, when it is necessary to conduct an examination of design estimates. As a rule, even reputable firms spend only hundredths of percent of their revenue on research and development. Although in foreign countries, for example, in India, private investors spend half of the funds in scientific innovations. So, here is also a wide range of creativity for researchers, teachers and students.

However, at present, only $10 \%$ of all state educational and scientific organizations make a significant contribution to world and domestic science (Стенограмма заседания Совета..., 2016).

Currently, the Federal Center for Research in Land Use, Land Management, Soil Science and Cadastral Activities is urgently needed. It should determine and maintain priorities in various areas of scientific research, pre-project support for the development of the country and its regions, the development of the Russian space, the justification and construction of a new model of economic relations, including land relations, coordinate their financing, preserve scientific personnel and attract young researchers.

Unfortunately, for the vast majority of tutors researching activity is losing its attractiveness: the share of university professors participating in research has decreased from 38 to $16 \%$, or even less. About $80 \%$ of higher education programs are not based on scientific works. As a result, the overwhelming part of it turned into "college-level training, where they teach according to the best textbooks and rather reproduce knowledge than develop it" (Образование и общество...2007). The continuation of this trend may have irreversible consequences not only for education and science, but also for the prospects for state management of the socio-economic development of the Russian economy and its regions. It should be noted that the forms and mechanisms of integration of science, education and business in Russia don't have regulatory legal support, and even situated outside the existing legal framework. The Ministry of Education and Science of the Russian Federation has been attempting to rectify this situation, but so far these actions have not brought the expected result.

Integration as an organizational and economic process means, first of all, combining the resources of scientific and educational complexes, including their innovative potentials, and obtaining socioeconomic and commercial effects. It is supposed that the state will stimulate the development of simple and more advanced forms of integration, such as innovative consortia that unite universities, technical schools, colleges, scientific organizations, enterprises and, possibly, financial institutions, with the subsequent formation of sustainable innovation clusters.

An effective integration of education, science and industry will undoubtedly lead to an increase in the innovative potential of the Russian economy.

For example, the introduction of energy-saving technologies (and use of alternative energy sources) is a political program. It is necessary that the whole society understood the need to minimize the human impact on the environment. There are many modern alternatives - solar collectors (the basic element of energy-water storage), heat pipes (Levalle vacuum pipes), decreasing of air conditioning and increasing of energy recovery, heat recovery from effluents, the creation of dirt trap systems, creation of stainless steel effluents system, as well as creation of clean streets system as in Scotland where overhang take place along the passerby part of the streets. In this work, there should be a study and examination of the key problems of living arrangements; we need to support the implementation of original interdisciplinary projects of international and interregional significance. We also need new scientific research for the educational process. Universities should be more fruitful in science, create their own 
scientific schools, and attract students (Дмитриев, Межевич, 1982; Мухаметзянов, Гусев, Разяпов, 2015).

Integration processes can be developed in certain organizational forms: technological centers, universities, research and production associations, special economic zones, consulting firms, etc. We underline that it is necessary to create technological centers for small and medium businesses not only for rent and making money - instead of that, technological centers have to be the places where small enterprises can create and introduce new technologies under the leadership of interregional public structures.

Neither the Ministry of Education and Science of the Russian Federation, nor the regional departments of education and science, nor the heads of educational institutions can how to train and retrain specialists for an innovative economy and, as a result, the authority to strategic and tactical management of integration processes are in the hands of organizations with financial capabilities. These issues were discussed at the meetings of the Presidential Council on Science and Education in January and November of 2016. V.V. Putin emphasized that educational organizations must comply with the priorities of the country's scientific and technological development and "it is necessary to look beyond the horizon of one, or maybe even two decades, to analyze what competencies will be in demand in 10 or more years, and which specialists need to be trained today" (Стенограмма заседания Совета..., 2016, Стенограмма заседания Совета..., 2016).

Speaking about the economic conditions of integration, we think that negative socio-economic phenomena had and have a destabilizing effect on the development of science, education and business. Social and economic instability, sanctions, financial deficit, aging and inadequacy of the material and technical base to the modern needs of scientific and educational activities, reduction of young personnel and scientific and pedagogical workers due to low salary, economic weakness of organizations at the stage of involvement in market relations, lack of information - all these factors slow down our country. In market relations, the search for fundamentally new integration models is very important, the significant economic condition is the diversification of sources of financing for research and educational technologies (i.e. grants, contracts with business entities, the implementation of scientific developments, scientific support, consulting, expertise, information services, design, survey, organizational services, implementation of patents, licenses, etc.). A special role here should be played by scientific and technological innovations and creation of financial institutions with the participation of the state for stimulation of commercialization. The problem is that there is no demand for innovation or it remains relatively low. The scale of demand for new developments in comparison with China, India, and Brazil is about 4 times. At the same time, our state spends on innovation more than the UK, China, Japan, but in our technological and innovative zones, our developments are taken by China, Turkey, Hungary, the Czech Republic, but not Russian enterprises.

It is necessary to actively introduce scientific and educational consortia, effective technological centers and complexes on the basis of universities, venture capital funds, technology development funds, and investment funds to promote the development of small businesses in the scientific and technical field. However, the situation can be significantly changed only when the enterprises demand innovations and realize that this is their stability and future.

Unfortunately, the profession of a scientist has still no value in Russia. The 1990s, which were difficult for a national higher education, completely devalued the position of a professor and university teacher. The growth of Russian publications over the past 15 years was only $12 \%$, compared to tenfold in China and threefold in India. At the same time, in terms of the number of articles, China overtook us in 1997, and India in 2005. According to the Institute of Sociology of the Russian Academy of Sciences, the profession of a scientist is prestigious for only $8 \%$ of the country's inhabitants (Образование и общество..., 2007; Административно-управленческий портал, 2020). At the same time, in the USA, the profession of a scientist is the most prestigious for $51 \%$ of the population, very prestigious for $25 \%$ and prestigious for $20 \%$.

At the same time, the requirements for higher and secondary special education are increasing in our country. The business mainly introduces innovations that promise a profit. However, progress is not only new technologies and equipment; it is a revolution in thinking. For example, the knowledge gained on "extreme" compositions can also be applied to traditional ones, while obtaining fundamentally new results including those that bring considerable economic effect. This requires not only the introduction of innovations, but also the solution of such urgent problems as resource and energy efficiency, safety, ecology, long-term development of territories and such a concept as a "smart city" - now all this is synergetic life-planning systems, including land use and land management. 
In these conditions, the higher land management school and land management science are forced to change the way they function. Various educational organizations (usually commercial) are offering educational services, which are beyond the state standards, but meet new demands of business and public. We can develop another scheme adopted abroad - the departments of land management companies. This is a convenient form for supporting leading professors and teachers, and restoration of former respect and authority to the "professor" mission. A special role here is played by communication of scientists, teachers and entrepreneurs realized, in most cases, in the form of scientific forums, conferences, seminars, symposia, round tables, etc.

\section{Conclusions and proposals}

Nowadays domestic science, education and business in land management are at the stage of searching for effective viable forms of integration. They are built according to the network principle, which equalizes its participants, so different in institutional and organizational specifics. Boards of trustees, national, regional and international associations of networks, international focal points began to appear taking the role of initiator of integration processes, and subsequently, the role of a network manager that regulates the processes of interaction between science, education and business. It is the creation of flexible network structures based on multilateral agreements that unite universities, technical schools, colleges, scientific organizations, enterprises, innovative firms. Their further development can be considered one of the necessary conditions for the successful functioning of integration of scientific and technological complexes in land management. These priorities are also laid down in the Strategy for Scientific and Technological Development of Russia, approved by the President of the Russian Federation in November 2016.

\section{References}

1. Административно-управленческий портал (2020) (Administrative and administrative portal). Available at: http://www.aup.ru (In Russian)

2. Буров М.П. (2011) Экономические преобразования в стране в условиях глобализации: национальный и региональные аспекты (Economic transformations in the country in the context of globalization: national and regional aspects). М.: Дашков и Ко, 2011.502c. (In Russian)

3. Буров М.П., Чистяков Е.Г. (2016) Основы национальной экономики: учебник, 2-е издание, М.: Экономика, 463c. (In Russian)

4. Волков С.Н., Борисова М.В., Астахова Т.А., Денисов Д.А. (2019) О возможности и необходимости развития открытого аграрного образования в Российской Федерации (On the possibility and necessity of developing open agricultural education in the Russian Federation). Землеустройство, кадастр и мониторинг земель. №12. с. 5-14. (In Russian)

5. Волков С.Н., Косинский В.В. (2018) Использование земель сельскохозяйственного назначения в Российской Федерации (The use of agricultural land in the Russian Federation). Baltic Surveying 18, Ольштин, Польша. с.75-80. (In Russian)

6. Дмитриев А.В., Межевич М.Н. (1982) Город: проблемы развития (City: development challenges). Л.: Наука, 1982. 173c. (In Russian)

7. Мухаметзянов 3.Р., Гусев Е.В., Разяпов Р.В. (2015) Формирование теоретических и методологических основ повышения эффективности организационных решений для целей планирования (Formation of theoretical and methodological foundations for increasing the effectiveness of organizational decisions for planning purposes) Промышленное и гражданское строительство. 2015.№12. c.68-72. (In Russian)

8. Образование и общество: готова ли Россия инвестировать в своё будущее? (2007) (Education and society: is Russia ready to invest in its future?), Общественная палата РФ. - М.: ГУ-ВШЭ, 2007. 265c. (In Russian)

9. Путин В.В. Формирование цифровой экономики - это вопрос национальной безопасности. Заседание Совета по стратегическому развитию и приоритетным проектам (Shaping the digital economy is a matter of national security. Meeting of the Council for Strategic Development and Priority Projects). Available at: www.kremlin.ru/events/president/news/54983 (In Russian)

10. Стенограмма заседания Совета по науке по образованию при Президенте Российской Федерации от 21 января 2016 года (Transcript of the meeting of the Council on Science of Education under the President of the Russian Federation of January 21, 2016) (2016). Available at: http://www.kremlin.ru/events/president/news/51190 (In Russian)

11. Стенограмма заседания Совета по науке по образованию при Президенте Российской Федерации от 23 ноября 2016 года Transcript of the meeting of the Council on Science of Education under the President of the Russian Federation of November 23, 2016) (2016). Available at: http://www.kremlin.ru/events/president/news/53313 (In Russian) 
Information about authors:

Kosinsky Vladimir Vasilievich, Doctor of Economics, Professor, Academician of the Russian Academy of Natural Sciences, Honored Worker of Culture of the Russian Federation, Professor of the Land Management department of the State University of Land Use Planning, Russia, Moscow,. Kazakova str., 15, +7 (499) 261-6335, e-mail: kosinskij1@mail.ru

Burov Mikhail Petrovich, Doctor of Economics, Professor, Academician of the Russian Academy of Natural Sciences, Advisor to the Rector of the State University Land Use Planning on the University Development, Russia, Moscow, Kazakova str.,15, +7 (499) 261-31-46, e-mail: info@guz.ru 